\title{
FOLIAGE ACCUMULATIONS OF OSMUNDA LIGNITUM (OSMUNDACEAE) IN THE OLIGOCENE OF NORTHERN ITALY AND WESTERN GERMANY
}

\author{
ZLATKO KVAČEK ${ }^{1, *}$, EDOARDO MARTINETTO $^{2}$
}

\author{
${ }^{1}$ Institute of Geology and Palaeontology, Faculty of Science, Charles University, Albertov 6, 128 43, Prague 2, the Czech Republic; e-mail: \\ kvacek@natur.cuni.cz. \\ 2 Dipartimento di Scienze della Terra, Università degli Studi di Torino, Via Valperga Caluso 35, I-10125 Torino, Italy; e-mail: edoardo.martinetto@unito.it. \\ * correspoding author
}

Kvaček, Z., Martinetto, E. (2016): Foliage accumulations of Osmunda lignitum (Osmundaceae) in the Oligocene of northern Italy and western Germany. - Fossil Imprint, 72(3-4): 131-139, Praha. ISSN 2533-4050 (print), ISSN 2533-4069 (on-line).

\begin{abstract}
Accumulations of Osmunda (Plenasium) lignitum (GIEBEL) STUR fern foliage have been recently recovered in the Oligocene deposits of northern Italy at Cassinelle and western Germany at Niederpleis-1 (Sankt Augustin; Winterscheid 2006). They morphologically match other European records distributed from the Eocene to the Oligocene (- early Miocene). Material from both sites represents sterile pinnae compressions with preserved leaf anatomy. The data obtained on leaf cuticles correspond to most of the previous findings from Germany (Geiseltal, Seifhennersdorf, Haselbach) but cast doubts on some others based on dispersed cuticles (e.g. Zülpich). Comparison with living species of Osmunda (Plenasium) from east and south-east Asia revealed only minor differences in the epidermal structure and stress the close relationship with Osmunda banksiifolia (C. PRESL) KUHN distributed along valley streams from China, Japan to Indonesia, New Guinea and Philippines.
\end{abstract}

Key words: Osmunda, Osmundaceae, sterile foliage, epidermis, Oligocene, Italy, Germany, Europe

Received: August 15, 2016 | Accepted: November 22, 2016 | Issued: December 30, 2016

\section{Introduction}

Osmunda lignitum belongs among the characteristic ferns of the Eurasian Palaeogene. Occurrences of its sterile foliage have been recorded scattered all over the continent (Collinson 2001, Tian et al. 2016). Thanks to its distinctive venation patterns, even fragments of its sterile fronds/pinnae are recognizable, although not much is known about the fertile parts of this plant (Barthel 1976). In the present account we describe the second record from the Apennine Peninsula, from where one of the first descriptions of Osmunda lignitum was presented by Squinabol (1889) from scanty Oligocene material of the Santa Giustina site (Bonci et al. 2011). Our finding from the Oligocene of Cassinelle in northern Italy is noteworthy because there this fern forms a layer made up of condensed foliage remains. Such accumulations can also be found elsewhere in Europe, e.g. in the Palaeogene of England (Bournemouth - Gardner and Ettingshausen 1879, 1880; Bovey Tracey - Heer 1862, Unger 1864) and Germany (Geiseltal - Barthel 1976). For comparison we used the exquisitely preserved material from the late Oligocene locality Niederpleis-1 (Sankt Augustin) in Rhineland (Winterscheid 2006 - originally described as Pronephrium stiriacum (UNG.) KNOBLOCH et KVAČEK; own collections of
Z. Kvaček), which allowed leaf epidermal comparisons with its nearest living relative Osmunda banksiifolia (C. PRESL) KUHN distributed in east and south-east Asia.

\section{Geological setting}

The studied fossils come from an outcrop in northern Italy at Casinelle and an abandoned clay pit in western Germany at Niederpleis-1 (in Sankt Augustin). Both sites are new occurrences of Osmunda lignitum in these countries, where this fern was previous recovered at other sites.

\section{Cassinelle}

A deposit rich in compressed fern foliage was observed $200 \mathrm{~m} \mathrm{SSW}$ of the locality Casa Amione, located close to the village of Cassinelle (Alessandria province, NW Italy: Text-figs 1-2). The field observations in the year 2007 permitted to detect determinable plant remains in just two outcrops of this area, and only the site indicated by the arrow in Text-fig. 1 showed a concentration of fern foliage described here as Osmunda. Another outcrop, named the "palm outcrop" (marked as P in Text-fig. 1, most probably 


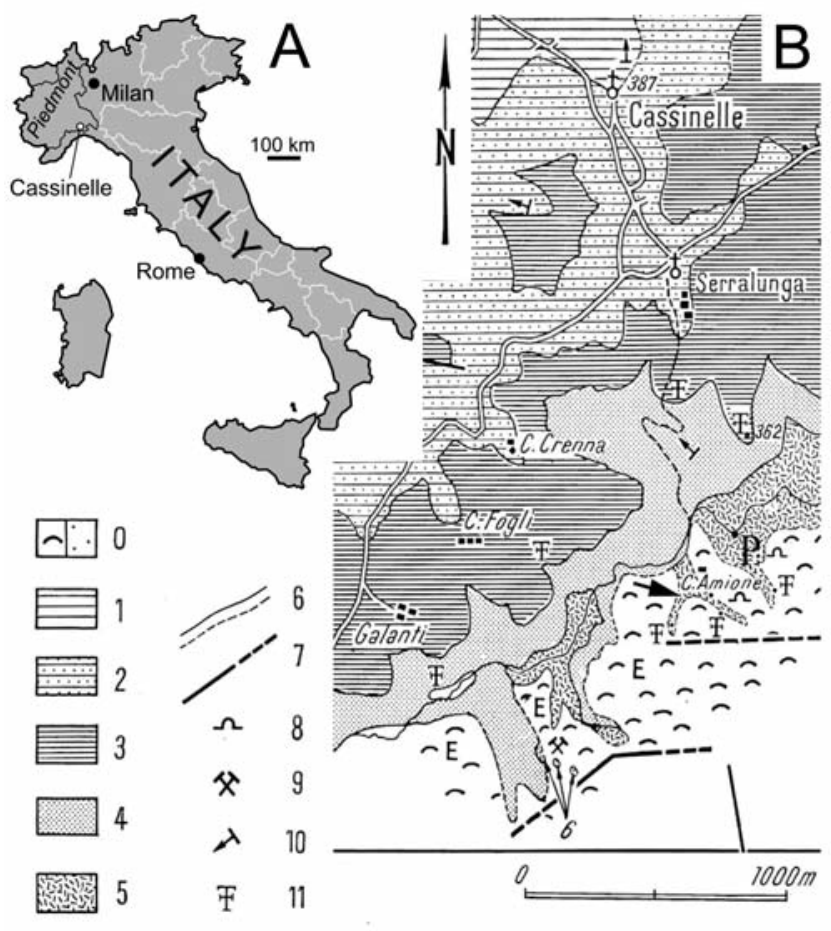

Text-fig. 1. A. Location of the site Cassinelle within Italy, B. Position with surrounding geological setting, modified from Lorenz (1969). The larger arrow close to C. Amione (= Casa Amione) indicates the outcrop with the fern layer; $P$ indicates another leaf-bearing outcrop where the compression of a palm leaf (Phoenicites sp.) was observed. - 0. Landslides and alluvial deposits (Quaternary), 1. Upper gray marls (marine lower Miocene), 2. Marine arenites of the Molare Fm. (Oligocene), 3. Lower gray marls (marine Oligocene), 4. Arenites and conglomerates (Oligocene), 5. Mainly conglomerates with subordinate sandy-silty lenses bearing continental or brackish fossils, 6. Observed and masked unit limit, 7. Observed or inferred (broken line) fault, 8. Old mining tunnel (lignite), 9. Old mine (lignite), 10. Dipping of layers, 11. Fossil site.

corresponding to the section figured by Lorenz 1969: 386 , fig. 36) yielded a badly preserved leaf fragment of Phoenicites sp. and an unidentified dicotyledonous leaf. In the "ferns outcrop" (Text-fig. 2) very fine sub-horizontally bedded dark grey sandstone was exposed in a thickness of ca. $80 \mathrm{~cm}$. Its basal $20 \mathrm{~cm}$ thick part was blackish due to abundance of compressed fern foliage.

The site belongs stratigraphically to the Molare Formation, which is the base of the up to $4 \mathrm{~km}$ thick Oligocene - Upper Miocene sedimentary succession of the Cenozoic Piedmont Basin (Dela Pierre et al. 1995, Barbieri et al. 2003). In the southern part of this basin, i.e. $50 \mathrm{~km}$ around Cassinelle, the subsidence started in the early Oligocene and caused a transgression, which progressed from N-NE to S-SW (Lorenz 1979), reaching the south westernmost sector of the basin only in the Chattian (Vannucci et al. 1997). The first result of such a transgression was the deposition of the coarse-grained, continental to shallow-water marine deposits of the Molare Formation, which accordingly is dated as early Oligocene in the eastern sectors, and as late Oligocene in the western sectors (Barbieri et al. 2003).

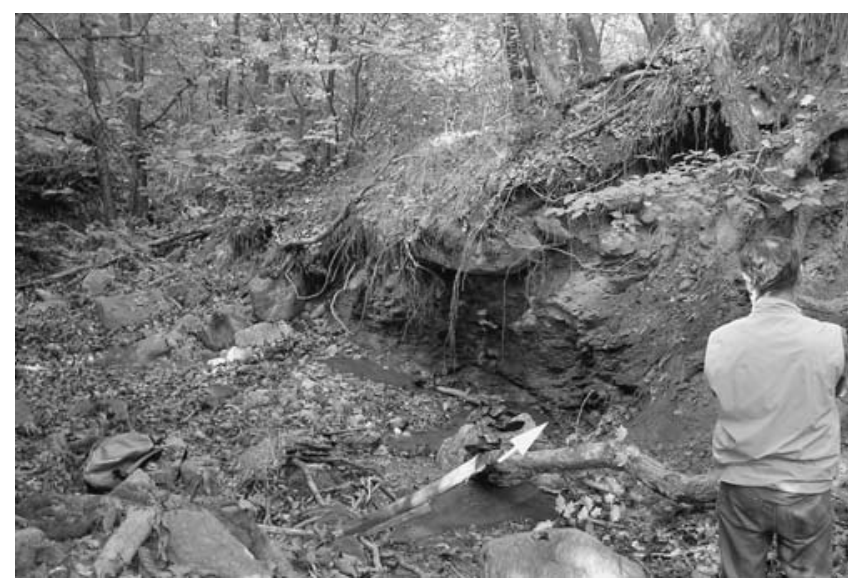

Text-fig. 2. Cassinelle, Casa Amione, view on the outcrop with the fern layer (white arrow).

Sandstones with a various degree of cementation are the prevailing lithology of the Molare Fm., but conglomerates are also common in the basal part, whereas pelitic layers or lenses are very rare. The upper part of this formation in the Cassinelle area is rich in coral, foraminifer and mollusk remains, which testify for a shallow-marine palaeoenvironment and indicate the late Oligocene in age (Chattian: Vannucci et al. 1997). The plant remains are mostly preserved at the base of the formation as coaly compressions. The frequent occurrence of large wood remains and root traces (Lorenz 1969: 387-388) indicates autochthonous to parautochthonous terrestrial plant assemblages in proximity of the ancient coast. In addition, a brackish mollusk assemblage was reported from an outcrop close to the ferns one (indicated by Lorenz (1969) as "200 m SSW of Casa Amione"). In general Lorenz (1969: 434) described in the Cassinelle area a vertical succession of facies from continental to brackish to shallow marine, and the ferns outcrop may expose either continental or brackish layers.

Lorenz (1979) reconstructed the environment for the late Oligocene as an emerged area to the south of the Cassinelle locality, and a marine basin to the north. Along the ancient coastline a few small continental basins were formed (e.g. Bagnasco, Cadibona, Santa Giustina), which preserved a rich fossil plant record, recently reported by Hably (2010) and Bonci et al. (2011). Plant remains are much rarer in the marine deposits, and only a species of Mastixia has been cited by Martinetto (2011) from there.

\section{Niederpleis-1}

The clay pit of the former firm "Großpeter and Lindemann" at Niederpleis in the Sankt Augustin town near Bonn (Text-fig. 3) is one of the Rhineland sites in the Siebengebirge Mts where the pelitic and lignite facies of the post-volcanic complex is accessible (Winterscheid 2006: 36). Here fossils were concentrated in clay layers within fluviatile deposits. The fossil bearing strata belong to the Köln Formation of late Oligocene age according to palynological dating (Von der Brelie et al. 1981). The site is not identical with the flora described from the drift facies of Niederpleis and containing a different mastixioid carpoflora described by 


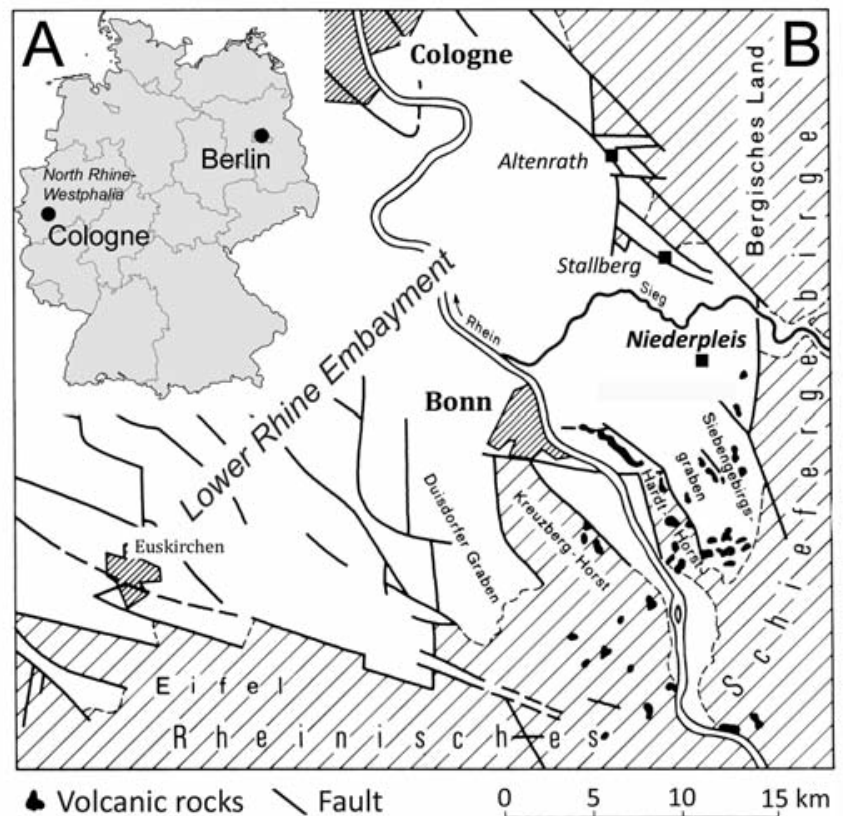

Text-fig. 3. A. Position of the investigated area within Germany, B. Geological/tectonical map of the Lower Rhine Embayment with the location of the clay pit at Niederpleis and two other Oligocene sites Altenrath and Stallberg (adopted after Winterscheid and Kvaček 2016).

Kirchheimer (1938), called "Niederpleis" by Winterscheid (2006). The exact dating is a matter of debate (Kilpper 1969: 16, Mai 1995: 57). The detailed geological setting of the area of Sankt Augustin has not been fully clarified so far and will be treated in separate monographs by Winterscheid and collaborators in future. For a more detailed information see Winterscheid (2006: 21-22, 35-37).

\section{Material and methods}

Foliage compressions from Cassinelle are preserved in firm gray irregularly bedded very fine sandstone. Leaf laminas are mostly fragmented into tiny pieces, which yielded cuticles after long (overnight) maceration in Schulze solution. After routine rinsing in $\mathrm{KOH}$, the obtained pieces show only traces of cell walls on the adaxial side and no cell structure on the abaxial epidermis, probably due to the high degree of coalification and extremely delicate nature of the abaxial cuticle. Packages of compressions from Niederpleis-1 were dissolved in water/diluted $\mathrm{H}_{2} \mathrm{O}_{2}$ and isolated pinnae removed on glass slides and embedded in glycerol or glycerol jelly. In this case maceration in Schulze solution was much shorter and better preparations were obtained even without rinsing in $\mathrm{KOH}$. The cuticle fragments of both leaf sides were transferred on slides into glycerol, covered by a cover glass and framed with nail varnish. A similar procedure was used for preparation of recent material. Most fossil specimens showed well preserved venation under oblique light, some isolated compressions were translucent even without bleaching. An Olympus camera and light microscope for the reproduction of details were used. The specimens studied and cuticle preparations are housed in the collections of the National Museum in Prague (NM) under the inventory numbers K 2761-62 (Cassinelle) and K 2758-2760, K 2765a, b (Niederpleis-1). Samples of recent ferns for epidermal preparations were obtained from the herbarium of the Charles University (designated as PRC).

\section{Systematic palaeontology}

\section{Osmundaceae MARTINOV \\ Osmunda LinNAEUS}

Subg. Plenasium (C. Presl) C. Presl

Osmunda (Plenasium) lignitum (GIEBEL) STUR

P1. 1, Figs 1-3, Pl. 2, Figs 1-5, P1. 3, Figs 1-2

1857 Pecopteris lignitum GIEBEL, p. 303, pl. 2, fig. 2a.

1870 Osmunda lignitum (GIEBEL) StUR, p. 5.

2006 Pronephrium stiriacum (UnGER) KNOBLOCH \& KVAČEK; Winterscheid, p. 61, pro parte, pl. 24, fig. 4.

2016 Osmunda lignitum (GIEBEL) STUR; Winterscheid and Kvaček, p. 46, fig. 2A.

Material studied: Sterile fern foliage with preserved cuticle structure, collections of the National Museum in Prague (NM) housed under the inventory numbers K 2761-62 (Cassinelle) and K 2758-2760, K 2765a, b (Niederpleis-1).

Fragmentary compressions of pinnae $12-15 \mathrm{~mm}$ wide or slightly wider, never as complete lengths, coarsely dentate, composed of oval apiculate sub-opposite pinnules, fused to $2 / 3$ of the length; midrib of pinna stout and straight, venation of pinnules free, midribs at an angle of $40^{\circ}-50^{\circ}$ to the main midrib, which reaches the apex, of almost the same thickness as other veinlets, secondary veins straight to slightly bent, often forked, craspedodromous, in 3-6 sub-parallel pairs, basal ending in the angular sinus, other bent along the margin (P1. 1-2). Adaxial side cuticles of medium thickness, smooth, anticlinal walls $\Omega$-shaped undulate demarcating irregularly polygonal, slightly elongate cells ca. 30-40 $\mu \mathrm{m}$ wide and 60-100 $\mu \mathrm{m}$ long, cuticle of abaxial side (obtained from Niederpleis-1 material only) much thinner and delicate, non-modified cells similar to those of adaxial side, stomata anomocytic, subparallel, widely elliptic, $50 \mu \mathrm{m}$ long, $30 \mu \mathrm{m}$ wide, stomatal ledges slightly bent, close together, stomatal slit linear (P1. 3, Figs 1-2).

For the typification and synonymy see Barthel (1976).

Discussion. Previously studied foliage of O. lignitum with preserved cuticle structure (e.g. Mathiesen 1965, Walther 1967, Barthel 1976, Mai and Walther 1985) provided details of pinnules, in particular venation (free catadromous) and epidermis cell structure (undulate anticlinal cell walls, stomata anomocytic, roundish, only on abaxial leaf side, longitudinally as well as irregularly orientated and subparallel) which does not differ from the data obtained from the presently described material. It thus proves the affinity of this sterile fern foliage to the subgenus Plenasium, namely to the similar living species Osmunda banksiifolia (C. PRESL) KuHN (Holttum in Chandler 1963, Mathiesen 1965), which differs only by slightly larger cells of the adaxial epidermis as well as larger stomata in the abaxial epidermis (Pl. 3, Figs 3-4). Our material does not permit comparisons of the whole plants including fertile parts. 
We can expand the European distribution as reviewed by Barthel (1976) and Collinson (2001) based on new records from the North Bohemian Eocene at Kučlín (Kvaček 2002, Kvaček and Teodoridis 2011), the Rhineland Oligocene, Germany (Altenrath - Winterscheid and Kvaček 2016, Niederpleis-1 - Winterscheid 2006: described as Pronephrium stiriacum, present study - P1. 2, Figs 1-5, P1. 3, Figs 1-2) and the new record from the Oligocene of Italy, which has also the above characteristics (Pl. 1, Figs 1-3).

Not all fossils ascribed so far to $O$. lignitum have in our opinion been correctly determined. In addition to the excluded records listed by Barthel (1976: 440) we also excluded dispersed cuticles from the Rhineland Miocene, which were assigned to Osmunda lignitum but which differ in stomatal details. Stomata in Osmunda are simple, anomocytic, broadly elliptic in outline, orientated subparallel and in cases of optimal preservation retaining polar T-pieces (Mathiesen 1965: text-fig. 5b, Walther 1967: pl. 4, figs 1-3, Barthel 1976: pl. 73, fig. 9, Walther in Mai and Walther 1985). Those wrongly assigned to Osmunda lignitum from the Miocene of the Zülpich Mine (Schultz 1962) differ in the thickened cutinized ring (Schultz 1962: pl. 5, figs 4-5, 7) and stomatal I-pieces (Schultz 1962: pl. 5, fig. 6) and belong to dispersed dicotyledonous cuticles (cf. Litke 1966: as NFu 23, Kilpper 1969: determined as Illicium ceriferum WEYLAND et al.). This observation may also apply to the abaxial cuticle from the Regis Mine with stomata illustrated by Kräusel and Weyland (1950: pl. 2, fig. 4, text-fig. 3 right), in which the stomata are irregularly orientated, as pointed out by Walther (1967).

Most of the records of Osmunda (Plenasium) lignitum in Europe have been found in the Eocene (e.g. Bournemouth, Geiseltal, Haselbach, Kučlín) and Oligocene (e.g. Bovey Tracey, Seifhennersdorf, Eger, Cornești-Aghireș) and only exceptionally in the lower Miocene (Jutland). The dating of some of the records previously assigned to the Miocene, namely Seifhennersdorf (Barthel 1976), was rectified and falls correctly into the Oligocene (Walther and Kvaček 2007). The new occurrence at Niederpleis-1 requires a more accurate independent dating. According to the pollen data (Von der Brelie et al. 1981) the strata with Osmunda are of late Oligocene age (see Winterscheid 2006).

This fern belongs to wetland ferns (Collinson 2002) and undoubtedly represents a paleo-subtropical element, at least in Europe, contrary to species belonging Osmunda subg. Osmunda of warm-temperate to temperate autecology. The accompanying vegetation corresponds to paratropical to subtropical broad-leaved forests dominated by evergreen Lauraceae, Hamamelidaceae, Fagaceae and palms, with accompanying deciduous Arcto-tertiary elements. The chronostratigraphical distribution of Osmunda lignitum in Europe is suggestive of the situation in East Asia, where this fern did not cross the Palaeogene/Neogene boundary and was replaced by another species of the Plenasium subgenus, O. totangensis (COLANI) GuO (Tian et al. 2016), probably synonymous with Osmunda bromeliaefolioides MATSUO (cf. Tanai 1970). The scarcity of frost-sensitive Osmunda lignitum in the European Neogene may explain the gap in circumboreal distribution of $O$. lignitum in the Cenozoic over most boreal Asia, namely the former Soviet Union and boreal North America.
Presl (1831) was the first botanist who recognized this group of ferns in the collections of Czech explorer Tadeus Haenke, collected in Luzon, Philippines. Tadeus Haenke never returned to Europe, but from South America, he sent his collection of plants to Hamburg, where Kašpar Sternberg subsequently learned about them, and arranged for them to be shipped to the Prague museum. The type specimen of Plenasium was later on transferred to the collection of the Charles University (PRC). The extant species of Osmunda subg. Plenasium have been interpreted in various ways, partly with the aid of fossil records (Bobrov 1967, Bomfleur et al. 2015). Our study may only add confirmation of the evolutionary as well as ecological stasis of the fossil Osmunda subg. Plenasium since the Palaeogene.

\section{Acknowledgements}

The authors thank Piero Giuntelli, for the precious information on the Cassinelle fossil site; Anna d'Atri and Pietro Mosca for providing geological information. The keepers of herbaria of the Charles University (PRC) allowed to access to the recent foliage of Osmunda and sampling. We are thankful to Vasilis Teodoridis for help with illustrations and reviewer comments. This study was supported by the grant project of GA ČR (No 14-23108S).

\section{References}

Barbieri, C., Carrapa, B., DiGiulio, A., Wijbrans, J., Murrell, G. (2003): Provenance of Oligocene synorogenic sediments of the Ligurian Alps (NW Italy): Inferences on belt age and cooling history. - International Journal of Earth Sciences, 92: 758-778. https://doi.org/10.1007/s00531-003-0351-x

Barthel, M. (1976): Farne und Cycadeen. - In: Eozäne Floren Geiseltales. Abhandlungen des Zentralen Geologischen Instituts (Paläontologische Abhandlungen), 26: 439-498.

Bobrov, A. E. (1967): Semeystvo Osmundaceae (R.Br.) Kaulf., ego sistematika i geografiya [The family Osmundaceae (R.Br.) Kaulf., its geography and taxonomy]. - Botanicheskiy Zhurnal, 52(11): 1600-1610. (in Russian)

Bomfleur, B., Grimm, G. W., McLoughlin, S. (2015): Osmunda pulchella sp. nov. from the Jurassic of Sweden - reconciling molecular and fossil evidence in the phylogeny of modern royal ferns (Osmundaceae). - BMC Evolutionary Biology, 15: 126 (25 pp.). DOI 10.1186/ s12862-015-0400-7

Bonci, M. C., Vannucci, G., Tacchino, S., Piazza, M. (2011): Oligocene fossil leaves of the Perrando Collection: history, preservation, and paleoclimatic meaning. Bollettino della Società Paleontologica Italiana, 50(3): 145-164. https://doi.org/10.4435/BSPI.2011.14

Chandler, M. E. J. (1963): Revision of the Oligocene floras of the Isle of Wight. - Bulletin of the British Museum (Natural History), Geology, 6(3): 323-383.

Collinson, M. E. (2001): Cainozoic ferns and their distribution. - Brittonia, 53(2): 173-235. https://doi.org/10.1007/BF02812700

Collinson, M. E. (2002): The ecology of Cainozoic ferns. Review of Palaeobotany and Palynology, 119: 51-68. https://doi.org/10.1016/S0034-6667(01)00129-4 
Dela Pierre, F., Mikhailov, V., Polino, R. (1995): The tectonosedimentary evolution of the tertiary basins in the western Po plain: kinematics inferred from subsidence curves. - In: Polino, R., Sacchi, R. (eds), Atti del Convegno Rapporti Alpi-Appennino e guide alle escursioni - Peveragno (CN) 31 maggio - 1 giugno 1994. Accademia Nazionale delle Scienze, Scritti e documenti, 14: 129-146.

Gardner, J. S., Ettingshausen, C. (1879): A monograph of the British Eocene flora, volume 1, part I [Filices]. Monograph, The Palaeontographical Society, 33(151): $1-38$.

Gardner, J. S., Ettingshausen, C. (1880): A monograph of the British Eocene flora, volume 1, part II [Filices]. Monograph, The Palaeontographical Society, 34(157): 39-58.

Giebel, C. (1857): Palaeontologische Untersuchungen. Zeitschrift für die gesammten Naturwissenschaften, 10: 301-317.

Hably, L. (2010): The Early Oligocene flora of Santa Giustina (Liguria, Italy) - Revision and comparison with the flora of the Tard Clay Formation. - Rivista Italiana di Paleontologia e Stratigrafia, 116: 405-420.

Heer, O. (1862): On the fossil flora of Bovey Tracey. Philosophical Transactions of the Royal Society, London, 152: 1039-1086. https://doi.org/10.1098/rstl.1862.0043

Kirchheimer, H. (1938): Beiträge zur näheren Kenntnis der Mastixioideen-Flora des deutschen Mittel- bis Oberoligozäns. - Beihefte zum Botanischen Centralblatt, B, 58: $303-375$.

Kilpper, K. (1969): Verzeichnis der im mittelren und unteren Rheinland gefundenen Großreste von Tertiärpflanzen (von 1821 bis 1968). - Ruhrland- und Heimatmuseum der Stadt Essen, Essen, 148 pp.

Kräusel, R., Weyland, H. (1950): Kritische Untersuchungen zur Kutikularanalyse tertiärer Blätter. I. - Palaeontographica, Abt. B, 91: 8-88.

Kvaček, Z. (2002): Late Eocene landscape, ecosystems and climate in north Bohemia with particular reference to the locality Kučlín near Bílina. - Bulletin of the Czech Geological Survey, 77: 217-236.

Kvaček, Z., Teodoridis, V. (2011): A Late Eocene flora of Kučlín near Bílina in North Bohemia revisited. - Acta Musei Nationalis Pragae, Series B - Historia Naturalis, 67(3-4): 77-82.

Litke, R. (1966): Kutikularanalytische Untersuchungen im Niederlausitzer Unterflöz. - Paläontologische Abhandlungen, B - Paläobotanik, 2(2): 193-426.

Lorenz, C. (1969): Contribution à l'ètude stratigraphique de l'Oligocène et du Miocène inférieur des confins LiguroPiemontais (Italie). - Atti dell'Istituto di Geologia dell'Università di Genova, 6(2), 253-888.

Lorenz, C. (1979): L'Oligo-Miocène ligure: Un example de transgression. - Bulletin de la Société Géologique de France, Sér. 7, 21(4): 375-378. https://doi.org/10.2113/gssgfbull.S7-XXI.4.375

Mai, D. H. (1995): Tertiäre Vegetationsgeschichte Europas. Gustav Fischer Verlag, Jena, Stuttgart, New York, 691 pp.

Mai, D. H., Walther, H. (1985): Die obereozänen Floren des Weißelster-Beckens und seiner Randgebiete. - Abhandlungen des Staatlichen Museums für Mineralogie und Geologie zu Dresden, 33: 5-176.
Martinetto, E. (2011): The first mastixioid fossil from Italy and its palaeobiogeographic implications. - Review of Palaeobotany and Palynology, 167: 222-229. https://doi.org/10.1016/j.revpalbo.2011.08.004

Mathiesen, F. J. (1965): Palaeobotanical investigations into some cormophytic macrofossils from the Neogene Tertiary lignites of central Jutland. Part I: Introduction and Pteridophytes. - Bioloiske Skrifter udgivet af Det Konigele Danske Videskabernes Selskab, 14(6): 1-46.

Presl, C. B. (1831): Reliquiae Haenkeanae, seu Descriptiones et icones plantarum, quas in America Meridionali et Boreali, in insulis Philippinis et Marianis collegit Thaddaeus Haenke. T. 2, Fasc. 1. - J. G. Calve, Praga, 56 pp.

Schultz, G. (1962): Zur Geologie der Braunkohlen bei Zülpich (Niederrheinische Bucht). - Neues Jahrbuch für Geologie und Paläontologie, Abhandlungen, 116(1): 89-118.

Squinabol, S. (1889): Contribuzioni alla flora fossile dei terreni terziari della Liguria. II. Caracee-Felci [Contributions to the fossil flora of Tertiary deposits of Ligury. II. Characeans-Ferns]. - Tipografia del Regio Istituto de' Sordo-Mutti, Genova, 62 pp. (in Italian)

Stur, D. (1870): Über zwei neue Farne aus den SotzkaSchichten von Möttning in Krain. - Jahrbuch der kaiserlich-königlichen geologischen Reichsanstalt, 20: $2-14$.

Tanai, T. (1970): Three Oligocene floras from the Kushiro coal field, Hokkaido, Japan. - Journal of the Faculty of Science Hokkaido University, series 4, geology and mineralogy, 14(4): 383-514.

Tian Ning, Wang Yong-Dong, Dong Man, Li Li-Qin, Jiang Zi-Kun (2016): A systematic overview of fossil osmundalean ferns in China: Diversity variation, distribution patter, and evolutionary implications. - Palaeoworld, 25(2): 149-169.

https://doi.org/10.1016/j.palwor.2015.05.005

Unger, F. (1864): Über einen in der Tertiärformation sehr verbreiteten Farn. - Sitzungsberichte der kaiserlichen Akademie der Wissenschaften, mathematisch-naturwissenschafliche Classe, 49: 289-279.

Vannucci, G., Piazza, M., Pastorino, P., Fravega, P. (1997): Le facies a coralli coloniali e rodoficee calcaree di alcune sezioni basali della Formazione di Molare (Oligocene del Bacino Terziario del Piemonte, Italia nord-occidentale) [The calcareous facies with colonial corals and rodophyceans of some basal sections of the di Molare Formation (Oligocene of the Tertiary Piedmont Basin, north-west Italy)]. - Atti Società Toscana Scienze Naturali, Memorie, 104A: 13-39. (in Italian)

Von der Brelie, G., Hager, H., Weiler, H. (1981): Pollenflora und Phytoplankton in den Kölner Schichten sowie deren Lithostratigraphie im Siegburger Graben. - Fortschritte in der Geologie von Rheinland und Westfalen, 29: 21-58.

Walther, H. (1967): Ergänzungen zur Flora von Seifhennersdorf (Sachsen). I. Teil. - Abhandlungen des Staatlichen Museums für Mineralogie und Geologie zu Dresden, 12: 259-277.

Walther, H., Kvaček, Z. (2007): Early Oligocene flora of Seifhennersdorf (Saxony). - Acta Musei Nationalis Pragae, Series B - Historia Naturalis, 63(2-4): 85-174. 
Winterscheid, H. (2006): Oligozäne und untermiozäne Floren in der Umgebung des Siebengebirges (südliche Niederrheinische Bucht). - Documenta naturae, 158(1+2): $1-298+299-485$.

Winterscheid, H., Kvaček, Z. (2016): Late Oligocene macrofloras from fluviatile siliciclastic facies of the Köln Formation at the south-eastern border of the Lower Rhine Embayment (North Rhine-Westphalia, Germany). - Acta Palaeobotanica, 56(1): 41-64.

https://doi.org/10.1515/acpa-2016-0005

\section{Explanations of the plates}

\section{PLATE 1}

Osmunda (Plenasium) lignitum (GIEBEL) STUR

1. Accumulation of pinnae on one bedding plane, Cassinelle, Italy, late Oligocene. NM-K 2762a, scale bar $10 \mathrm{~mm}$.

2. Detail of the previous figure, scale bar $10 \mathrm{~mm}$.

3. Fragmentary coaly pinna, Cassinelle, Italy, late Oligocene. NM-K 2761, scale bar $5 \mathrm{~mm}$.

\section{PLATE 2}

Osmunda (Plenasium) lignitum (GIEBEL) STUR

1. Isolated compressions of pinnae, Niederpleis-1, Germany, late Oligocene. NM-K 2758a-c, scale bar $10 \mathrm{~mm}$.

2. Isolated pinna, Niederpleis-1, Germany, late Oligocene. NM-K 2765a, scale bar $10 \mathrm{~mm}$.

3. Detail of the coaly pinna shown in Pl. 2, Fig. 1 middle, NM-K 2758b, scale bar $5 \mathrm{~mm}$.

4. Detail of the coaly pinna shown in Pl. 2, Fig. 1 right, NM-K 2758c, scale bar $5 \mathrm{~mm}$.

5. Detail of the coaly pinna shown in Pl. 2, Fig. 2, NM-K 2765a, scale bar $5 \mathrm{~mm}$.

\section{PLATE 3}

Osmunda (Plenasium) lignitum (GIEBEL) STUR

1. Abaxial cuticle with undulate anticlinal walls and stomata. Niederpleis-1, Germany, late Oligocene. NM-K 2758bB, scale bar $100 \mu \mathrm{m}$.

2. Adaxial cuticle with undulate anticlinal walls. Niederpleis-1, Germany, late Oligocene. NM-K 2758bB, scale bar $100 \mu \mathrm{m}$.

Osmunda (Plenasium) banksiifolia (C. PRESL) KUHN

3. Abaxial cuticle with undulate anticlinal walls and stomata. Sorsogon, Recent. Coll. PRC Haenke, scale bar $100 \mu \mathrm{m}$.

4. Adaxial cuticle with undulate anticlinal walls. Sorsogon, Recent. Coll. PRC Haenke, scale bar $100 \mu \mathrm{m}$. 


\section{PLATE 1}
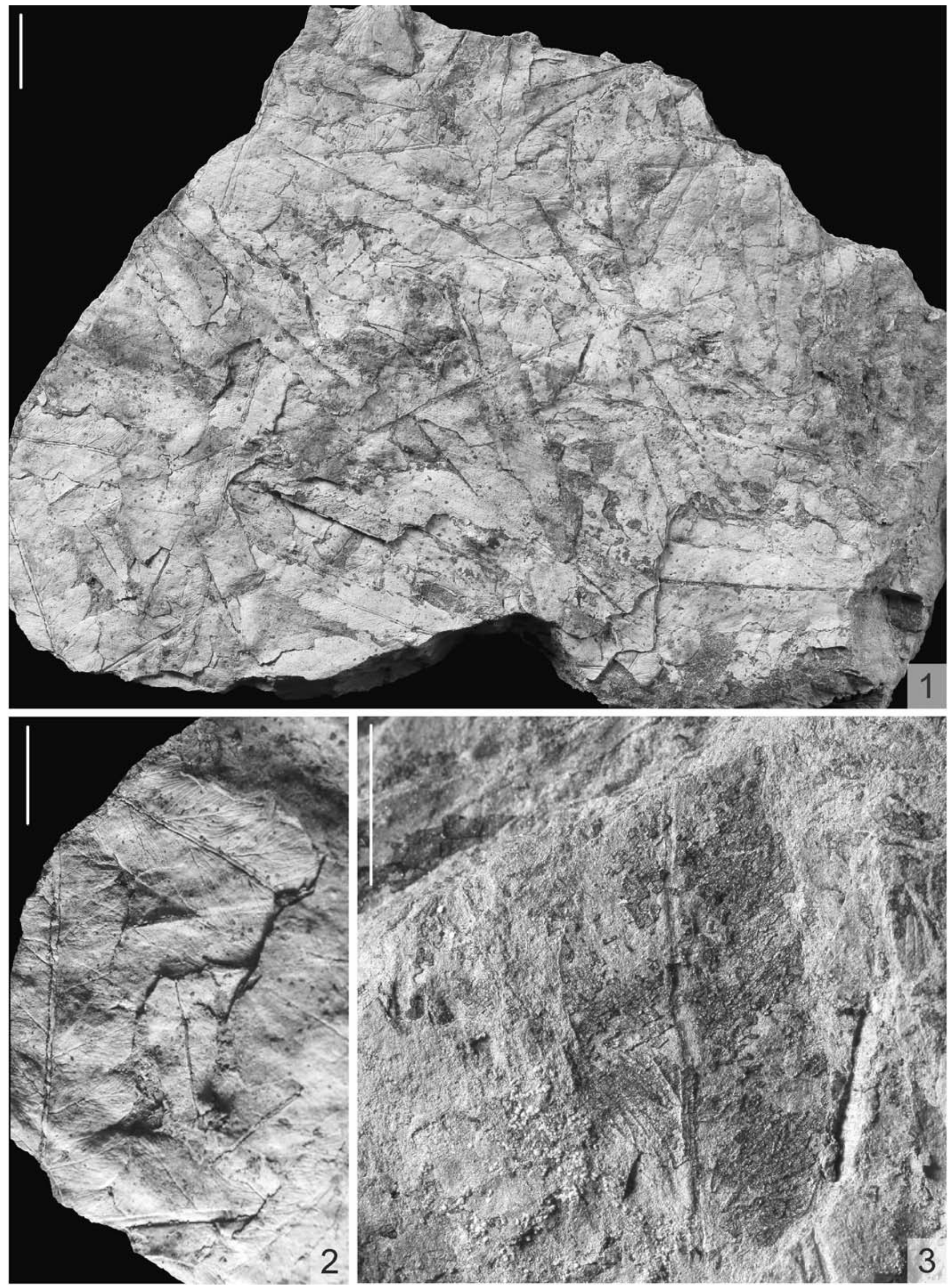
PLATE 2
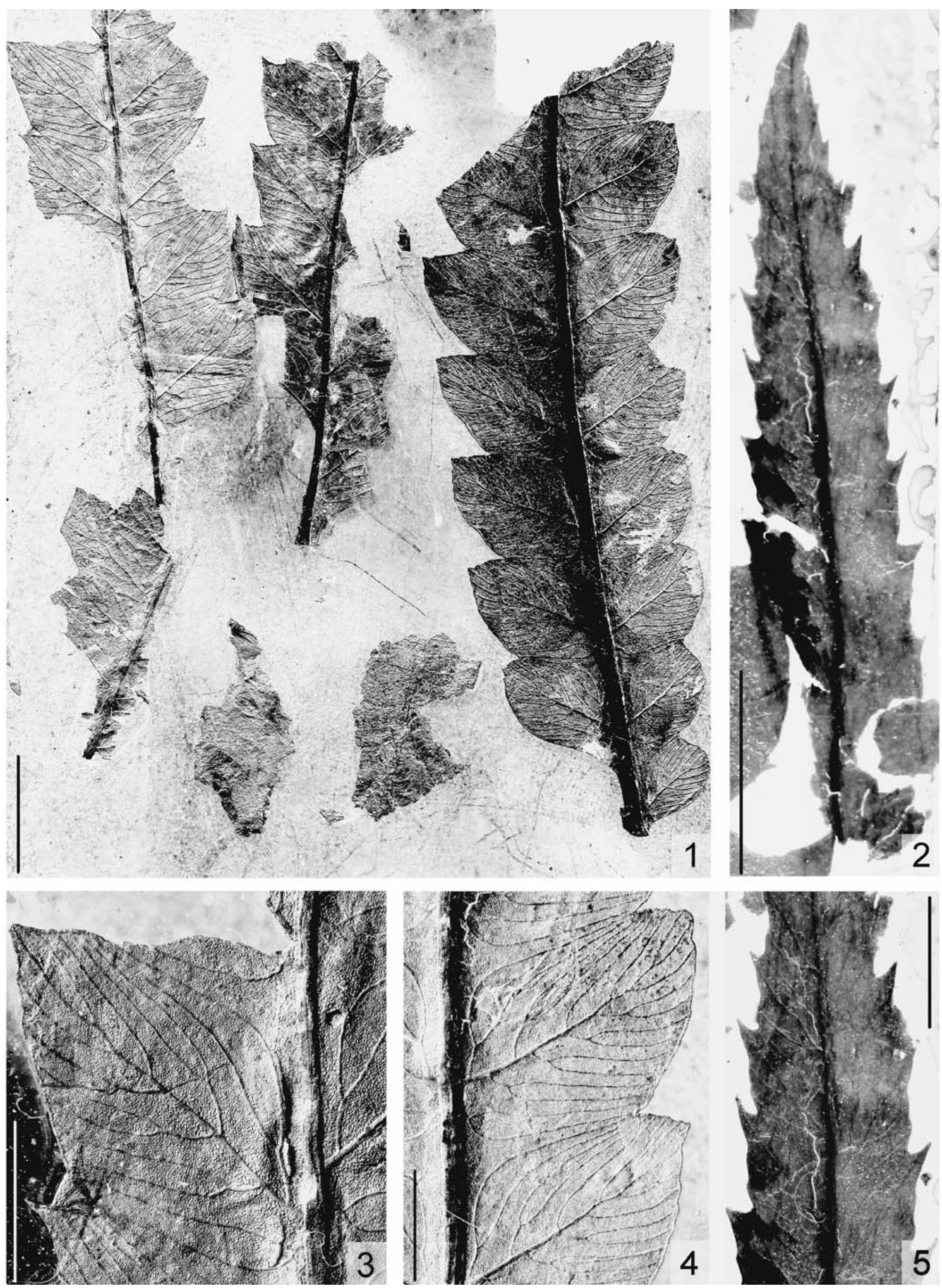


\section{PLATE 3}
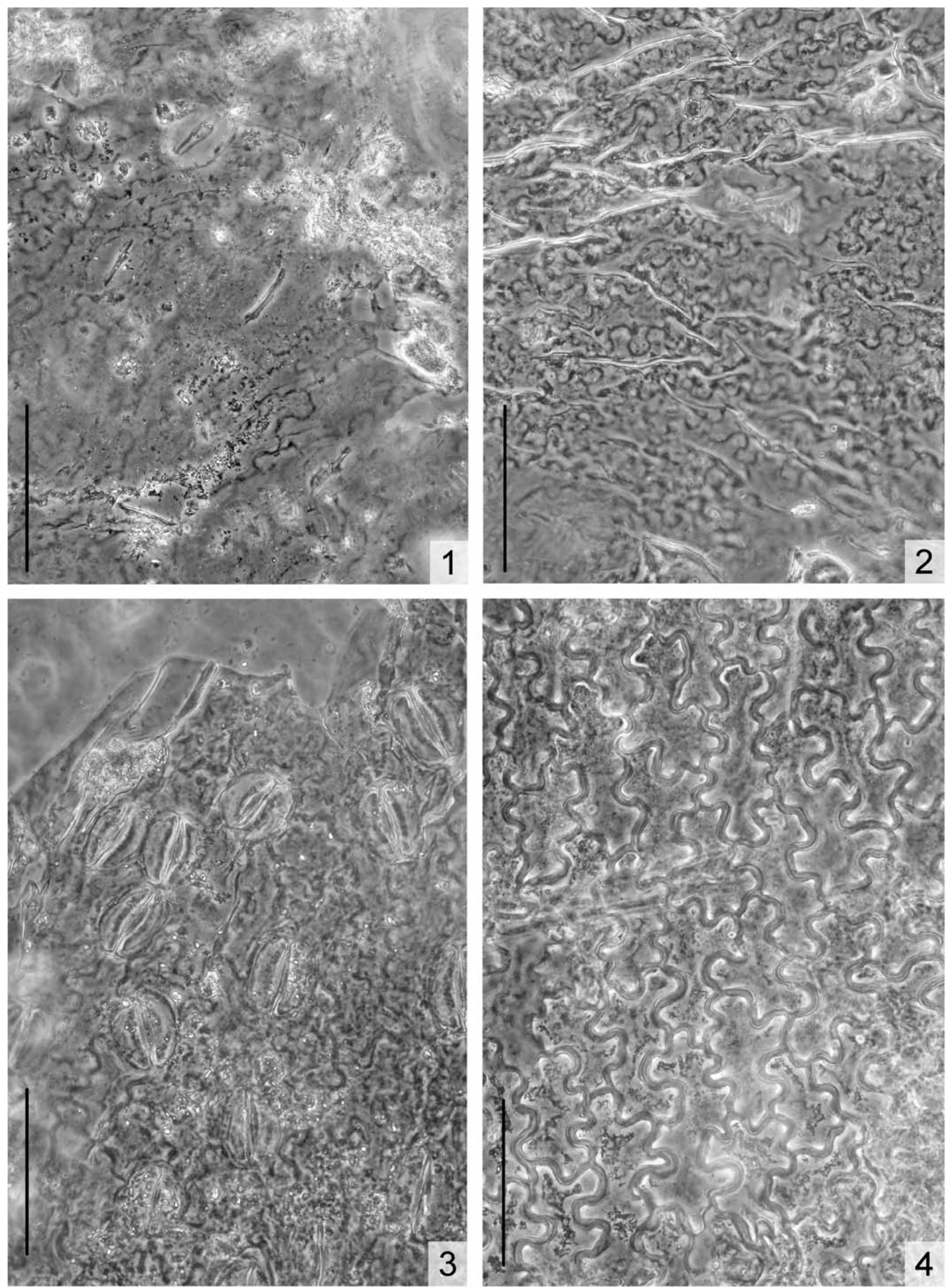